\title{
胆汁中遊離 $\mathrm{Ca}^{2+}$ イオン（活性型）測定法の確立と その動態に関する研究
}

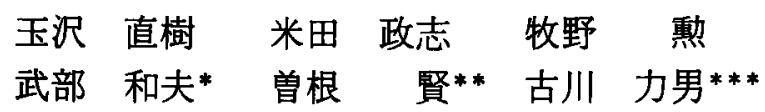

要 旨：胆汁中遊離カルシゥムイオン $\left(\mathrm{Ca}^{2+}\right)$ は生物学的活性を有し，不溶性 $\mathrm{Ca}$ 塩の形成に関 与する。著者らは $\mathrm{Ca}^{2+}$ selective electrode 法による胆汁中 $\mathrm{Ca}^{2+}$ の実用的測定法を開発し，その 測定值の妥当性を分画分子量 1,000 による限外沪過液中 $\mathrm{Ca}$ 值と比較し確認した. 本法を用いて 胆石症患者 14 例（純コレステロール石 8 例，混合石 6 例）の胆囊胆汁中 $\mathrm{Ca}^{2+}$ 濃度を胆汁脂質濃 度とともに測定した。胆汁中総 $\mathrm{Ca}$ 濃度は $9.46 \pm 3.42 \mathrm{mg} / \mathrm{d} l$ で胆汁脂質濃度との間に強い相関 が認められた。一方胆汁中 $\mathrm{Ca}^{2+}$ 濃度は $2.40 \pm 0.63 \mathrm{mg} / \mathrm{d} l$ で胆汁脂質に非依存性で添注一定値

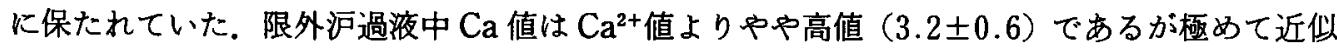

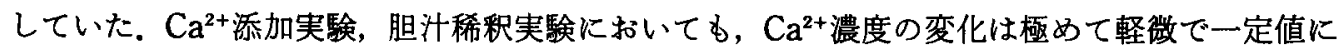
保たれることが示された。 これらの事実は混合ミセルの胆汁酸が $\mathrm{Ca}^{2+}$ 可逆的に結合・解離を くり返し $\mathrm{Ca}^{2+}$ 濃度を一定に保持している事を示唆している。

索引用語：胆汁中遊離 $\mathrm{Ca}^{2+}$ イオン $\mathrm{Ca}^{2+}$ selective ion meter 胆汁酸ミセル 胆裹胆汁 胆石症

\section{緒言}

胆计中 $\mathrm{Ca}$ は遊離 $\mathrm{Ca}$ イオン $\left(\mathrm{Ca}^{2+}\right)$ と結合型 $\mathrm{Ca}$ と から成る. 前者は生物学的活性を有し, 不溶性 $\mathrm{Ca}$ 塩の 形成に関与するが 汁酸と結合した複合体で, 生物学的活性を有しないも のの溶存性である．生体内における不溶性 $\mathrm{Ca}$ 塩の形 成は $\mathrm{Ca}^{2+}$ 活性度と $\mathrm{Ca}$ sensitive anion $\left(\mathrm{CO}_{3}{ }^{2-}\right.$, $\mathrm{HPO}_{4}{ }^{2-}$, ビリルビン, パルミチン酸など $\left.{ }^{33}\right)$ の活性度の 皘が各不溶性 $\mathrm{Ca}$ 塩の溶解度積を越えた場合に出現す る4. したがって，胆汁中に拈ける $\mathrm{Ca}^{2+}$ 活性度を測定す ることは石灰化現象 ${ }^{5,6)}$ の pathogenesis と関連し，極 めて重要であるが7.8)，その正確な簡易測定法が確立さ れておらず本分野の研究は立遅れの状態にある.

最近 $\mathrm{Ca}^{2+}$ selective electrode 法による測定が試み られているが, 胆汁試料は粘性が高いため, 計機が円 滑に作動せず，また分析試料も比較的大量必要とする 欠点もあって正確な分析值の報告は乏しい。

今回著者らは $\mathrm{Ca}^{2+}$ selective electrode 法での測定

\footnotetext{
* 弘前大学第 3 内科

** 弘前大学薬剤部

***五所川原西北病院
}

〈受付日61年 4 月 14 日 $>$
試料容器を改良することにより，実用的な簡易測定法 を開発し，本法を用いてヒト胆畺胆汁中 $\mathrm{Ca}^{2+}$ 様相を検 討したので報告する。

\section{对象ならびに研究方法}

\section{1. 対象}

胆衰内胆石症14例について胆毫摘出術を施行中に胆 震胆汁を直接穿刺で採取した。摘出胆石は肉眼的分類 により純コレステロール石 8 例, 混合石 6 例であった。

\section{2. 胆汁中総 $\mathrm{Ca}$ 港度の測定}

胆震胆汁を $1 \%$ 塩化ストロンチウム溶液で20倍に稀 釈し， Ca を原子吸光計(AA 855型, Japan Jarell Ash) で定量した。

\section{3. 胆汁中 $\mathrm{Ca}^{2+}$ 濃度の測定}

胆汁中 $\mathrm{Ca}^{2+}$ 濃度の測定は測定試料容器に改良を加 えた $\mathrm{Ca}^{2+}$ selective electrode 法 (Ion selective meter, type PN 9415, philips Ltd.)によった. 本試料容器 (東 要電波社試作，東京）はFig. 1に示したごとく，直径 $1 \mathrm{~cm}$ のガラス製円筒形で底部に小型スターラー, 側面 にセラミック製の小結合部を有する．測定方法は胆汁 $1.0 \mathrm{ml}$ を試料容器に入れ, それをビーカー内の $\mathrm{KCl}$ 飽 和溶液中に立たせた後, reference electrode $\mathrm{KCl}$ 飽 和溶液中へ, $\mathrm{Ca}^{2+}$ selective electrode を胆汁中へ插入 


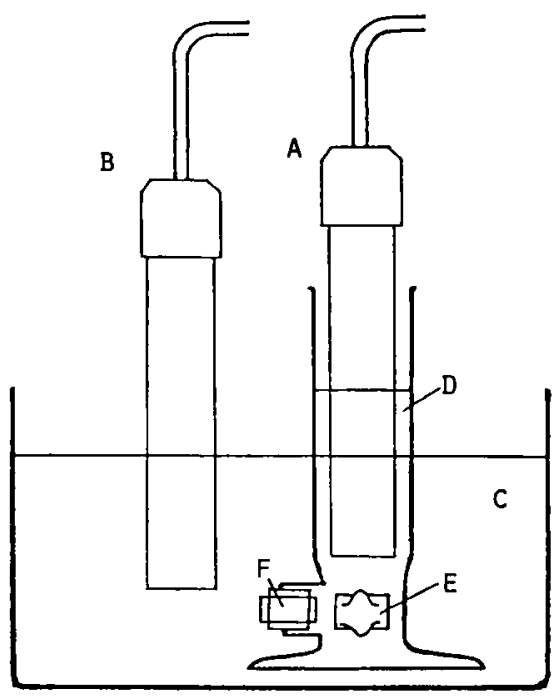

Fig. 1 A schema of a new type of sample countainer.

A new type of sample container was used for the analysis of a small amount of bile. This countainer is a glass cylinder with a stirrer at the bottom and a ceramic junction on the side wall. The container containing $1.0 \mathrm{~m} l$ of gallbladder bile was then stood in a saturated $\mathrm{KCl}$ solution inside a beaker.

A; $\mathrm{Ca}^{2+}$ selective ion meter (type PW 9415, Philips Ltd.), B ; reference electrode, C ; saturated $\mathrm{KCl}$ solution, $\mathrm{D}$; gallbladder bile sample, $\mathrm{E}$; a stirrer, F ; a ceramic junction.

し， 1 分後のディジタル表示値から $\mathrm{Ca}^{2+}$ 濃度を読み とった。本法の再現性は極めて良好で, トリプリケイ トでのCV\%は1\%以内であった。

\section{4. 胆霍胆汁の Ultrafiltrable $\mathrm{Ca}$ 裟度の测定}

今回著者らが行った胆汁中 $\mathrm{Ca}^{2+}$ 測定法の正確性を

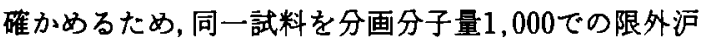
過を行いUltrafiltrable Ca の测定を行った 胆譱胆汁 $0.4 \mathrm{~m} l$ を分画分子量 1,000 のディスポーザル 限外沪過ユニット（日本ミリポフ, 東京, 試作品)に 入れ, ニニット内に窒素ガス $3 \mathrm{~m} l$ を注入して限外汇過 を開始し，沪液 $0.2 \mathrm{~m} l$ を得た段階で終了した（約 3 時 間).沪液中の Ultrafiltrable Ca 濃度は前述の原子吸 光法で測定した。

\section{5. 限外沪過ユニットの精度の検定}

分画分子量 1,000 限外汇過ュニットの分離能につ いては TBPB (Tetrabromophenol blue, 東京化成工 業, 分子量986) と TPPS ( $\alpha, \beta, \gamma, \delta$.Tetraphenylpor. phinetrisulfonic acid disulfonic acid salt tetrahydrate, 同化化学, 分子量1051）を使用して検定を行っ た，つまり两物質の0.1\%容液を作製の上，各溶液 1.0 $\mathrm{m} l$ を限外沪過し, 沪過前後で吸光度差から阻止率を 算出した (TBPB $608 \mathrm{~nm}$, TPPS $413 \mathrm{~nm}$ ). その結果阻 止率は TBPB 33.2\%, TPPS 94.7\%であり，本ュニッ トによる cut-off が良好であることを確認した。

次いで Ultrafiltrable Ca 濃度の再現性を 4 検体の 各トリプリケイトで検討し，その結果 CV\%は8.1士 3.3\%であった。一方, 限外沪過操作中に胆汁中 Ca が フィルター膜面に選択的に吸着される可能性の有無を 検討した。それには胆汁試料を限外沪過し，得られた 沪液を再度限外沪過を行い，最初の沪液と第 2 回目の 沪液について Ultrafiltrable Ca を測定したところ，両 者間に有意差が存在しなかった．本所見により膜面に 対する Ca の選択的吸着はないるのと判定した。

\section{6. 胆汁脂質の測定}

胆漖胆汁を20倍量の Folch 液（クロロホルム：メタ ノール2：1）に加えた後，超音波溶槽内で約15分間 振偒し，遠心してその上清を胆汁脂質の抽出液とした。 本抽出液の一部を用いて胆汁酸は $3 \alpha$-hydroxysteroid dehydrogenase による酵素法（ステログノスト3 $\alpha$ ，第 一化学薬品, 東京) リン脂質は酵素法 (Phospholipids B test, Wako, 和光純薬，大阪），コレステロールは醭 素法 (cholesterol C test Wako, 和光純薬, 大阪) $に$ より測定した。をた胆计試料の $\mathrm{pH}$ は $\mathrm{pH}$ メーター (Horiba $\mathrm{pH}$ meter M-BS 型) で測定した.

\section{結 果}

\section{1. 胆霍胆汁における胆汁脂澌棈成}

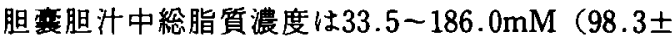
48.9）であり，広い変動幅を認めた．各胆计脂質の構 成\%は胆汁酸 $69.5 \pm 7.1 \%$ ，リン脂質 $23.5 \pm 6.8 \%$, コ

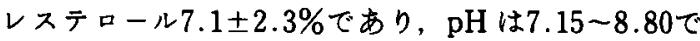
あった (Table 1).

\section{2. 胆震胆汁中総 $\mathrm{Ca}$ および $\mathrm{Ca}^{2+}$ 濃度}

Table 1にまとめたごとく, 胆亦胆汁中総 $\mathrm{Ca}$ 濃度は $5.6 \sim 16.3 \mathrm{mg} / \mathrm{d} l(9.5 \pm 3.4)$ であり，広範囲な変動幅 を認めた。一方 $\mathrm{Ca}^{2+}$ 濃度は一定範囲值にあり,

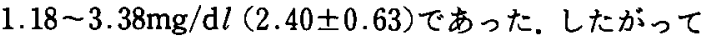
総 $\mathrm{Ca}$ と $\mathrm{Ca}^{2+}$ との間には統計学的有意の相関は認め られなかった，胆汁中総 $\mathrm{Ca}$ 濃度は胆汁脂質ないし胆 汁酸濃度の増加に伴って上昇し各々の間に高い相関関 係が存在した ${ }^{10}$ ) (Fig. 2)(相関係数は胆汁脂質と0.925, 胆汁酸と0.918). しかし胆汁中 $\mathrm{Ca}^{2+}$ と胆汁脂質の間に 
Table 1 Biliary lipid composition and calcium level in gallbladder bile of patients with cholesterol gallstone.

\begin{tabular}{c|c|c|c|c|c|c|c|c}
\hline $\begin{array}{c}\text { sample } \\
\text { number }\end{array}$ & $\mathrm{pH}$ & $\begin{array}{c}\mathrm{TBL} \\
(\mathrm{mM})\end{array}$ & $\begin{array}{c}\mathrm{BA} \\
(\%)\end{array}$ & $\begin{array}{c}\mathrm{PL} \\
(\%)\end{array}$ & $\begin{array}{c}\mathrm{CH} \\
(\%)\end{array}$ & $\begin{array}{c}\mathrm{T} . \mathrm{Ca} \\
(\mathrm{mg} / \mathrm{d} l)\end{array}$ & $\begin{array}{c}\mathrm{UF} . \mathrm{Ca} \\
(1,000) \\
(\mathrm{mg} / \mathrm{d} l)\end{array}$ & $\begin{array}{c}\mathrm{Ca}^{2+} \\
(\mathrm{mg} / \mathrm{d} l)\end{array}$ \\
\hline 1. & 8.09 & 33.5 & 57.3 & 29.6 & 13.1 & 5.6 & 2.2 & 1.18 \\
2. & 7.15 & 46.6 & 58.2 & 37.8 & 4.1 & 5.8 & 2.3 & 1.65 \\
3. & 8.80 & 47.6 & 63.2 & 26.7 & 10.1 & 5.9 & 3.6 & 2.22 \\
4. & 7.78 & 56.7 & 66.1 & 26.3 & 7.6 & 6.9 & 4.1 & 2.97 \\
5. & 7.72 & 67.4 & 59.5 & 36.4 & 4.2 & 8.8 & 4.1 & 3.38 \\
6. & 7.45 & 67.9 & 71.1 & 21.8 & 7.1 & 7.2 & 3.7 & 2.56 \\
7. & 8.75 & 78.1 & 75.3 & 19.2 & 5.5 & 7.5 & 3.2 & 2.97 \\
8. & 7.55 & 94.6 & 73.3 & 20.0 & 6.8 & 10.1 & 3.8 & 2.56 \\
9. & 7.91 & 101.4 & 73.3 & 18.4 & 8.3 & 7.4 & 2.5 & 1.82 \\
10. & 7.80 & 114.3 & 80.7 & 14.1 & 5.3 & 11.6 & 2.5 & 1.92 \\
11. & 8.15 & 144.6 & 74.6 & 18.5 & 6.9 & 14.0 & 2.7 & 1.71 \\
12. & 8.45 & 164.6 & 73.6 & 20.7 & 5.8 & 10.6 & 3.5 & 2.87 \\
13. & 8.01 & 172.7 & 75.3 & 18.2 & 6.5 & 14.8 & 2.7 & 3.00 \\
14. & 8.16 & 186.0 & 71.2 & 21.1 & 7.6 & 16.3 & 3.3 & 2.75 \\
\hline Mean & 7.98 & 98.3 & 69.5 & 23.5 & 7.1 & 9.5 & 3.2 & 2.40 \\
\pm SD & \pm 0.45 & \pm 48.9 & \pm 7.1 & \pm 6.8 & \pm 2.3 & \pm 3.4 & \pm 0.6 & \pm 0.63 \\
\hline
\end{tabular}

TBL : total biliary lipid concentration, $\mathrm{BA}$ : bile acid, PL : phospholipid, $\mathrm{CH}$ : cholesterol,

T.Ca : total calcium, UF.Ca : ultrafiltrable calcium cut-off molecular weight 1.000

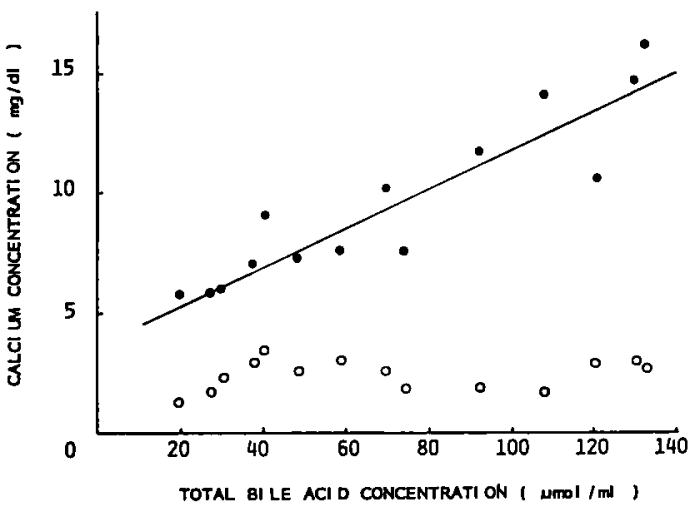

Fig. 2 Relationship between total or ionized calcium and total bile acid concentration in gallbladder bile.

Total biliary calcium (O) increased in proportion to total bile acid and there was a highly significant correlation between them, and the regression line was $y=0.082 x+3.694(r=0.918$, $\mathrm{p}<0.01$ ). While $\mathrm{Ca}^{2+}(\mathrm{O})$ showed a much narrower range and didn't correlated with total bile acid concentration ( $r=0.273$, no significance).

は相関がなく，したがって，総 Caに対する $\mathrm{Ca}^{2+} の$ 比 率は胆汁脂質 $100 \mathrm{mM}$ 以上の濃厚胆汁で20.3\%であ

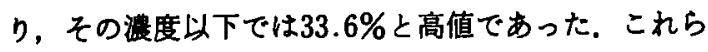

の成績は胆汁中総 $\mathrm{Ca}$ は胆汁脂質の変化に依存し, $\mathrm{Ca}^{2+}$ は非依存性でほぼ一定值に保たれることを示唆 している.

3. 胆基胆汁中 $\mathrm{Ca}^{2+}$ と Ultrafiltrable $\mathrm{Ca}$ との比較 胆汁試料を分画分子量1,000で限外汇過すると汇液 中に出現する Ultrafiltrable $\mathrm{Ca}$ は $\mathrm{Ca}^{2+} に$ 加文胆汁酸 monomerないし dimer と結合した Ca が若干混入す る. 今回分析した胆栾胆汁についてはその值が $2.2 \sim 4.1 \mathrm{mg} / \mathrm{d} l$ (3.2 20.6$)$ のほぼ一定範囲値にあり (Table 1), ion selective electrode 法による $\mathrm{Ca}^{2+}$ 值 よりるやや高值であるが，極めて近似し両者間に高い 相関を認めた $(r=0.83)$.

これらの所見は著者らが改良型試料容器を使用した $\mathrm{Ca}^{2+}$ 測定法の正確度が高いことを保証するすので あった。

\section{4. $\mathrm{Ca}^{2+}$ 添加実験}

胆变胆汁中 $\mathrm{Ca}^{2+}$ 灌度の変化を検討するため, 試料 No. 10 (総胆汁酸瀑度 $92.2 \mathrm{mM}$, 総 Ca $11.6 \mathrm{mg} / \mathrm{d} l$ ) を 用いて $\mathrm{Ca}^{2+}$ 添加実験を行った. 方法は $\mathrm{Ca}^{2+を ~} 0,0.02$ ， $0.04,0.08 \mathrm{mg}$ 含有する $\mathrm{CaCl}_{2}$ 溶液 $5 \mu l$ を胆汁 $1 \mathrm{~m} l$ に加 占，十分混和後 2 時間室温放置して総 $\mathrm{Ca} と \mathrm{Ca}^{2+}$ を上 記方法で湘定した。その結果はFig. 3に示してある が, 添加 Ca の回収率は84.6士7.5\%でそのほとんどは 結合型 $\mathrm{Ca}$ 分画として回収され， $\mathrm{Ca}^{2+}$ 瀑度の変化は極 


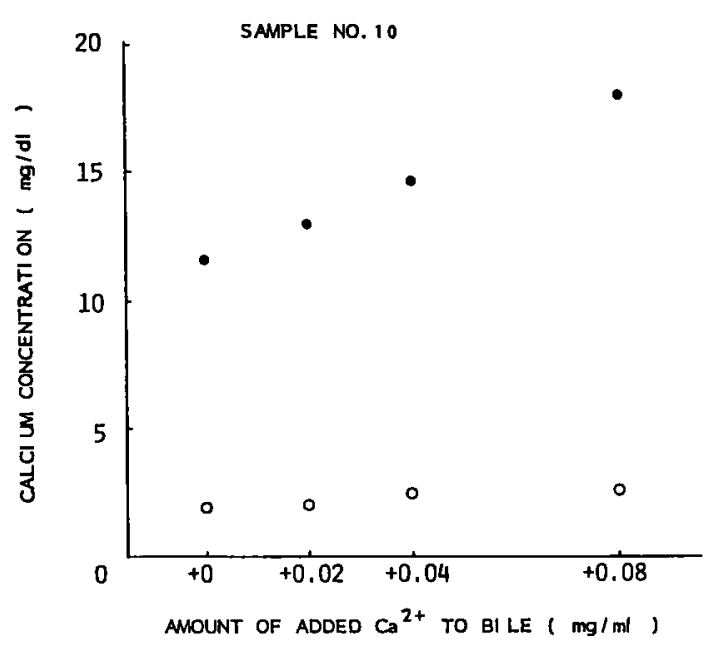

Fig. 3 Recovery of free calcium ion added to gallbladder bile.

The five ul of $\mathrm{CaCl}_{2}$ solution containing $0,0.02$, 0.04 and $0.08 \mathrm{mg}$ as free $\mathrm{Ca}^{2+}$ ion was added to every $1 \mathrm{~m} l$ of gallbladder bile of sample number 10 , of Which total bile acid is $92.2 \mathrm{umol} / \mathrm{ml}$ and total calcium $11.6 \mathrm{mg} / \mathrm{d} l$, and then the change in total and $\mathrm{Ca}^{2+}$ levels was determined. As illustrated in this figure, a large part of added $\mathrm{Ca}^{2+}$ was recovered as bound calcium and an increase of $\mathrm{Ca}^{2+}$ concentration remained very slight. The recovery of added $\mathrm{Ca}^{2+}$ to bile samples was calculated to be $84.6 \pm 7.5 \%$. closed circle : total calcium, open circle : ionized calcium.

めて軽微であった。したがって総 $\mathrm{Ca}$ に対する $\mathrm{Ca}^{2+}$ の 比率は添加 $\mathrm{Ca}^{2+}$ 量の増加に伴ない減少し，16.6\%(添 加量 0) 加ら $13.9 \%$ (添加量0.08mg) へと変化した.

5. 胆萁胆汁の稀釈に伴う $\mathbf{C a}^{2+}$ の变化

試料 No. 14 （総胆汁酸 $132.5 \mathrm{mM}$, 総 Ca $16.3 \mathrm{mg} /$ $\mathrm{d} l)$ の胆变胆汁を生理的食塩水で $4 / 3$ 倍， 2 倍， 4 倍に 稀积し，その後の各稀釈液における総 $\mathrm{Ca}$ および $\mathrm{Ca}^{2+}$ 濃度を上記方法で測定した。その結果はFig. 4に示し たが，総 $\mathrm{Ca}$ 濃度は稀积倍数に比例して低下し，一方

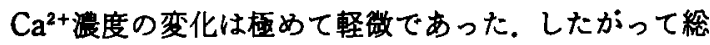
$\mathrm{Ca}$ に対する $\mathrm{Ca}^{2+}$ の比率は稀釈前 $16.9 \%$ から 2 倍稀积 $27.9 \% ， 4$ 倍稀釈 $47.6 \%$ と增加した。

\section{考察}

今回著者らは $\mathrm{Ca}^{2+}$ selective meter の試料用容器を 改良することにより従来测定が困難であったヒト胆竞 胆计中 $\mathrm{Ca}^{2+}$ の測定を容易とし，本法を用いて総 $\mathrm{Ca}$ 浱 度は胆汁脂質依存性に変化するのに対して，Ca $\mathrm{Ca}^{2+}$ 濃度

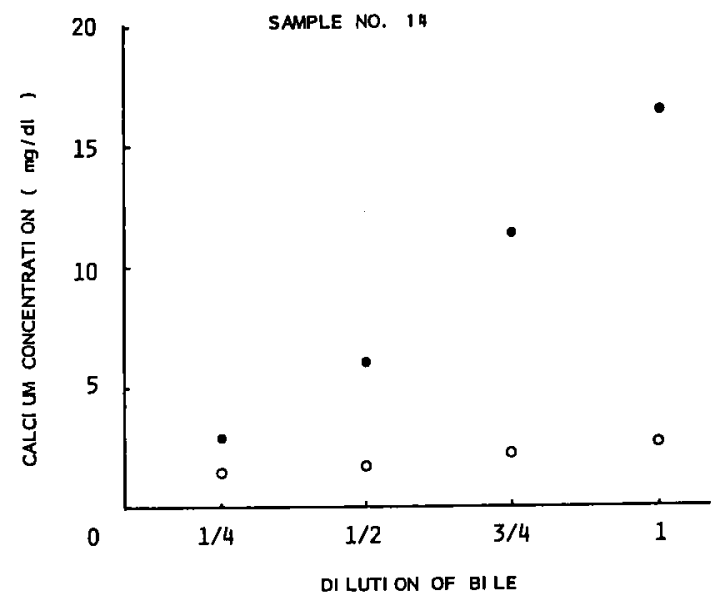

Fig. 4 Change of $\mathrm{Ca}^{2+}$ level due to dilution of gallbladder bile.

Gallbladder bile sample number 14 , with a total bile acid level of $132.5 \mathrm{umol} / \mathrm{m} l$ and total calcium level of $16.3 \mathrm{mg} / \mathrm{d} l$ was diluted $1: 4 / 3,1: 2$ and $1: 4$ with saline solution. And then the change in total and $\mathrm{Ca}^{2+}$ levels were determined. As illustrated in this figure, total $\mathrm{Ca}$ decreased linearly in proportion to the degree of dilution, but a decrease of $\mathrm{Ca}^{2+}$ levels was very slight. closed circle: total calcium, open circle: ionized calcium.

はほぼ一定值に保たれていることを明らかにした。

胆汁中総 $\mathrm{Ca}$ は原子吸光計の利用により容易に測定 できるが，結合型 $\mathrm{Ca}$ と遊離イオン型を分離定量する ことは簡単でなく，現在までそれに関する報告は極め て乏しい(1)。胆汁中 $\mathrm{Ca}$ はその大部分が混合ミ七ルな いし非ミセル型の胆汁酸と複合体を形成し溶存してい る. 混合ミセルの分子量は胆变内において $11,000^{12)}$ か ら150,000 ${ }^{13)}$ に達すると推定されているため1976年 Sutor らは分画分子量10,000で胆汁を限外沪過し, Ultrafiltrable Ca を混合ミセル結合型 Caから分離し

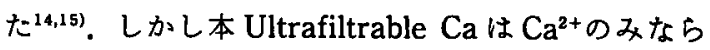
ず，分子量 1 万以下の物質と結合した $\mathrm{Ca}$ 含まれる ので, 正確な $\mathrm{Ca}^{2+}$ 値とはいい難い久点を有した. 1980 年同じく Sutor らは ion selective electrode 法による 胆汁中 $\mathrm{Ca}^{2+}$ 值を報告したが们，奇妙なことにそれ以降 追試報告はほとんど見あたらない.おそらく市販の血 中 $\mathrm{Ca}^{2+}$ 測定用装置を用いて胆计中 $\mathrm{Ca}^{2+}$ の測定を試み た場合，粘稠度が高いため，胆汁試料と electrode との 接触が十分でなく，測定値が異常低值となるためと思 われる.今回著者らは従来からのion selective 
electrode 法を利用するものの試料容器に改良を加克 た.その特徵は reference electrode がセラミック結合 部と $\mathrm{KCl}$ 飽和溶夜を介し胆汁試料と液絡されている ため, ion selective electrode のみを胆汁試料中に插入 することで測定可能となり，胆汁試料を $1.0 \mathrm{~m} l$ に節約 できること，底部のスターラーによる擋找で胆汁と $\mathrm{Ca}^{2+}$ selective electrode の接触が円滑となることが 利点である. 一方, 本法は同一試料のトリプリヶイト 湘定でCV\%が 1 \%以内であること, 分画分子量 1,000 で cut-off した Ultrafiltrable Ca 值と良く合致するこ とから信頼度の高いことが保証されたと考えられる。

Sutor はコレステロール胆石症での胆襄胆汁で, $\mathrm{Ca}^{2+}$ 濃度は2.56 6.92mg/d $l$ で総 $\mathrm{Ca}$ 濃度と強く相 関すると報告している゙1)。 しかし今回著者らの成績は $\mathrm{Ca}^{2+}$ 濃度が $1.18 \sim 3.38 \mathrm{mg} / \mathrm{d} l$ で一定範囲値にあり, 総 $\mathrm{Ca}$ 濃度との間に有意の相関を見出すことができな かった.さらに $\mathrm{Ca}^{2+}$ 濃度の一定性については, その後 の $\mathrm{Ca}^{2+}$ 添加試験や胆汁稀釈試験からも保証された.

胆汁酸と $\mathrm{Ca}^{2+}$ の結合様相については従来から, 抱合 胆汁酸溶液7,14,16,17)，人工モデル胆汁 ${ }^{18)}$, 動物 ${ }^{18)}$ 扣よび ヒト胆汁 14,17)を用いin vitroで検討されてきたが，結 合能は $\mathrm{pH}^{(18)}$, リン脂質 ${ }^{18)}$ ，電解質 ${ }^{20)}$ の影響を受け，さ らに胆汁酸の種類で異ることが既に明らかにされてい る.今回我々の見出した胆亳胆汁中 $\mathrm{Ca}^{2+}$ 濃度が一定範 井值に保持される現象は, 混合ミセルの胆汁酸が $\mathrm{Ca}^{2+}$ と可逆的結合・解離をくり返し buffer 様作用をはたし ていることを示唆するものである。

本研究で胆汁中活性型 $\mathrm{Ca}$ ，つまり $\mathrm{Ca}^{2+}$ 濃度の測定 が容易となったことより,今後各種肝胆道疾患の pathogenesis と $\mathrm{Ca}^{2+}$ 役割について検討を進めるこ とが必要と思われる。

\section{文献}

1) Wosiewitz U: Limy bile and radiopaque, calcified gallstones. Path Res $167: 273-286,1980$

2) Been JM, Bills PM, Lewis D: Microstructure of gallstones. Gastroenterology 76 : 548-555, 1979

3) Sutor DJ, Wooley SE: A statistical survey of the composition of gallstones in eight countries. Gut $12: 55-64,1971$

4) Moore EW: The role of calcium in the pathogenesis of gallstones : $\mathrm{Ca}^{2+}$ electrode studies of model bile salt solutions and other biologic system: With an hypothesis on structural reguirements for $\mathrm{Ca}^{2+}$ binding to proteins and bile acids. Hepatology $4: 228 \mathrm{~S}-243 \mathrm{~S}, 1984$

5) Bateson MC, Bouchier IAD, Trash DB, et al : Calcification of radiolucent gallstones during treatment with ursodeoxycholic acid. Br Med J $283: 645-646,1981$

6) Schoenfield LJ, Lachin JM, The NCCS Streeing Committee, et al : National cooperative gallstone study; a controled trial of the efficacy and safety of chenodeoxycholic acid for dissolution of gallstones. Ann Intern Med $95: 257$ $-282,1981$

7) Moore EW, Celic L, Ostrow D: Interactions between ionized calcium and sodium taurocholate: Bile salts are important buffers for prevention of calcium containing gallstones. Gastroenterology 83 : 1079-1089, 1982

8) McLean FC, Hasting AB: The state of calcium in the fluids of the body. I. The conditions affecting the ionization of calcium. J Biol Chem $108: 285-322,1935$

9) Moore EW : Ionized calcium in normal serum, ultrafiltrates and whole blood determination by ionexchange electrodes. J Clin Invest $49: 318$ $-334,1970$

10）玉沢值樹, 米田政志, 牧野 勲, 他：胆汁中活性型 $\mathrm{Ca}$ 分画の測定と胆汁脂質との関連性. 肝缄 26 : 543, 1985

11) Sutor DJ, Wilkie LI, Jackson MJ: Ionized calcium in pathological human bile. $\mathrm{J} \mathrm{Clin}$ Pathol 33: 86-88, 1980

12) Bouchier IAD, Cooperband SR: Isolation and characterization of a macromolecular aggregate associated with bililubin. Clin Chim Acta 15: 291-302, 1967

13) Carey MC, Small DM: The caracteristics of mixed micellar solution with particular reference to bile. Am J Med 49:590-608, 1970

14) Sutor DJ, Wilkie LI: Calcium in bile and calcium salts in gallstones. Clin Chim Acta 79 : 119-127, 1977

15) Wilkie LI, Carter GH, Hallewell VA, et al : An apparatus for the anerobic ultrafiltration of bile and other biological fluids. Gut 17:652 -654, 1976

16) Rajapalan $N$, Lindenbaum $S$ : The binding of 
$\mathrm{Ca}^{2+}$ to taurine- and glycine- conjugated bile salt micelles. Biochem Biophy Acta 711: 62 $-74,1982$

17) Williamson BWA, Percy-Robb IW: The interaction of calcium ions with glychocholate micelles in aqueous solution. Biochem J $181: 61$ $-66,1979$

18) Williamson BWA, Percy-Robb IW : Contribution of biliary lipids to calcium binding in bile.
Gastroenterology $78: 696-702,1984$

19) Cummings SA, Hofmann AF: Physiologic determination of biliary calcium secretion in the dog. Gastroenterology 86:664-673, 1984

20) Moore EW, Dietsch JM : $\mathrm{Na}^{+}$and $\mathrm{K}^{+}$activity coefficients in bile and bile salts determined by glasselectrodes. Am J Physiol 206: 111-117, 1964

\title{
Determination of biliary ionized $\mathrm{Ca}^{2+}$ concentration and its aspect in human gallbladder bile
}

\author{
Naoki Tamasawa, Isao Makino, Masashi Yoneda, Kazuo TaKebE*, \\ Ken SONE** and Rikio KogaWA***
}

We analyzed total and ionized calcium in pathological human bile in association with biliary lipids. $\mathrm{Ca}^{2}+$ concentration was directly determined using conventional $\mathrm{Ca}^{2}+$ selective ion meter and a new type of sample container. The accuracy and precision of our ion selective electrode analysis were confirmed by similarity to ultrafiltrable Ca level cut-off molecular weight 1,000. Total Ca levels ranged from 5.6 to $16.3 \mathrm{mg} / \mathrm{d} l$, and these levels were well correlated with biliary lipid concentrations. Unlike total $\mathrm{Ca}, \mathrm{Ca}^{2+}$ concentration remained almost constant level $(2.40 \pm$ $0.63 \mathrm{mg} / \mathrm{d} l$ ), regardless of the change in biliary lipid concentration. This findings was confirmed by the recovery test for addition of $\mathrm{Ca}^{2}+$ and dilution test adding saline solution to gallbladder bile. In conclusion, total $\mathrm{Ca}$ level was dependent on biliary lipid concentration, while $\mathrm{Ca}^{2}+$ level was independent and kept a constant value, probably owing to the regulating role of the mixed micelle in gallbladder bile.

* The 3rd Department of Internal Medicine, Hirosaki University School of Medicine (Hirosaki)

** The Department of Pharmacy, Hirosaki University Hospital (Hirosaki)

*** The Department of Surgery, Seihoku Hospital (Goshogawara) 